Acta Universitatis Wratislaviensis • No 4055

Literatura i Kultura Popularna XXVII, Wrocław 2021

https://doi.org/10.19195/0867-7441.27.14

\author{
Adriana Sara Jastrzębska \\ ORCID: 0000-0003-0794-1383 \\ Uniwersytet Jagielloński
}

\title{
Narkopowieść latynoamerykańska: rzeczywistość z Szekspirem w tle
}

\begin{abstract}
Słowa kluczowe: Kolumbia, narkobiznes, powieść kryminalna, narkopowieść
\end{abstract}
Keywords: Colombia, drug trafficking, narco, crime fiction, narconovel

Gdyby William Szekspir tworzył współcześnie, byłby zafascynowany Ameryką Łacińską. Dla miłośnika mocnych sensacyjnych tematów, takich jak władza, ambicja, zdrada i zbrodnia, dla autora niestroniącego od przekraczania subtelnej granicy między rzeczywistością a fantastyką, twórcy złożonych, niejednoznacznych charakterów ludzkich Ameryka Łacińska ze swoją historią dyktatur, rewolucji, utopii i ich spektakularnych upadków stanowiłaby bowiem niewyczerpane źródło inspiracji. Zważywszy na rolę, jaką odgrywał teatr w XVI i XVII wieku, sądzę też, że tworzący współcześnie Szekspir sięgałby po gatunki i konwencje popularne, w tym w pierwszej kolejności powieść kryminalną, zwłaszcza w tej jej odmianie, która funkcjonuje w Ameryce Łacińskiej i wyrasta z jej specyficznych uwarunkowań historycznych, społecznych i kulturowych. Szekspira przecież bardziej interesowały emocje zbrodniarza i sama zbrodnia niż intelektualna praca nad jej wykryciem i wyjaśnieniem.

Te fascynacje i wybory niechybnie doprowadziłyby współczesnego Szekspira do opowieści ze świata narkobiznesu: tego obszaru działania późnego kapitalizmu, w którym jego własne cechy, groteskowo wyolbrzymione i zniekształcone, dają początek przerażającej rzeczywistości ${ }^{1}$. Świat dramatów Szekspira to świat przekraczania norm i wkraczania w ten tajemniczy i nieprzewidywalny obszar, który

${ }^{1}$ Na określenie tej fazy kapitalizmu i specyficznych dla niej praktyk meksykańska autorka Sayak Valencia używa słowa ,gore”, zapożyczonego ze świata filmów z krwawą przemocą na pierwszym planie. Zob. eadem, Capitalismo gore, Barcelona 2010. 
kryje się poza nimi. To także świat potężnych emocji i namiętności, świat ekstremów tam, gdzie chodzi zarówno o sukcesy, jak i spektakularne upadki. Konflikty rodzinne i moralne dylematy, błędy przynoszące dramatyczne konsekwencje, kwestie lojalności czy zdradzonych przyjaźni i przemoc podobne do tych, o których pisze Szekspir w Hamlecie, Makbecie, Królu Learze czy Otellu, znajdują dziś swe odbicie w swoistej kulturze narkobiznesu ${ }^{2}$, z której rodzi się narkopowieść, będąca centralnym tematem tego artykułu.

\section{Specyfika powieści kryminalnej w Ameryce Lacińskiej}

Nim jednak przejdziemy do narkopowieści jako takiej, warto powiedzieć parę słów o specyfice konwencji kryminalnej w literaturze latynoamerykańskiej. Powieść kryminalna zawsze jest bowiem owocem konkretnego momentu historycznego oraz określonej sytuacji społeczno-politycznej. W Europie utwory tego gatunku opowiadające o przekraczaniu norm prawa i porządku paradoksalnie zazwyczaj potwierdzały ich aktualność. Amerykańska czarna powieść z czasów wielkiego kryzysu już pokazuje świat, którego porządek jest tylko pozorny, a pod nim kryje się wszelkiego typu zepsucie, zło i korupcja. Powieść kryminalna w Ameryce Łacińskiej wychodzi z kolei z założenia - mówiąc w ogromnym uproszczeniu — że jakikolwiek stały i stabilny porządek prawny nie istnieje. Pod koniec XX wieku w poszczególnych krajach regionu pojawia się tak zwana nowa powieść kryminalna (neopolicial), w której enigma, tajemnica do rozwikłania zostaje odesłana na drugi plan, a istotniejsze niż odkrycie, kto dokonał zbrodni, jest wyjaśnienie dlaczego. Głównym motywem zbrodni stają się różnice wewnątrz społeczeństwa. Neopolicial jest więc w Ameryce Łacińskiej gatunkiem swoiście „zaangażowanym”, narzędziem pozwalającym diagnozować stan społeczeństwa. Odbija rzeczywistość, nierzadko inspirując się prawdziwymi wydarzeniami i autentycznymi zbrodniami. Wprowadza do powieści oralność; dominuje dialog lub monolog bohatera, a postaci charakteryzowane są poprzez swój idiolekt. Ponieważ postać zarówno detektywa, jak i policjanta działającego wyłącznie w służ-

2 Pojęcie narkokultury jest niezwykle złożone i doczekało się już publicystycznych i naukowych opracowań. Narkokultura to „kultura, w której dobre jest wszystko, co pozwala wyjść z biedy", kultura ostentacyjnej konsumpcji i zabawy, kultura przepychu i kiczu. Dotyczy przede wszystkim wzbogaconych na handlu narkotykami przedstawicieli uboższej części społeczeństwa, którzy aspirują do stylu życia warstw wyższych, czyniąc to w sposób przerysowany niejednokrotnie do granic groteski. Jednocześnie widać jej mocne zakorzenienie w ludowości i ludowym sposobie postrzegania świata (obyczajowość, religijność). W oczywisty sposób częścią tej kultury jest przemoc i plemienne rozumienie takich pojęć, jak lojalność czy honor. Narkokultura ma też swój język, szczególnie bogaty w słownictwo związane z narkotykami, bronią i zadawaniem śmierci. Na temat narkokultury zob. O. Rincón, Todos llevamos un narco adentro-un ensayo sobre la narco/cultura/telenovela como modo de entrada a la modernidad, „MATRZes” 7, 2013, nr 2, s. 1-33, https://bit.ly/3zaRNhq (dostęp: 15.07.2021); M. Zawierzeniec, Las voces sordas. El capital creativo del México contemporáneo en su contexto socio-cultural (1985-2015), Warszawa 2016, s. 197-220.

Literatura i Kultura Popularna XXVII, Wrocław 2021

(C) for this edition by CNS 
bie prawa to byty obce realiom latynoamerykańskim, neopolicial niejednokrotnie osadza w roli ,detektywa” intelektualistę — pisarza, dziennikarza, profesora, a jeśli już policjanta-detektywa, to $\mathrm{z}$ ambicjami literackimi ${ }^{3}$. Często też opowiada historię zbrodni z punktu widzenia ofiary lub sprawcy. Oddaje głos tym, którzy w oficjalnych dyskursach bywają zmarginalizowani. Można wręcz mówić o swoistej „,komercjalizacji marginesu” w literaturze latynoamerykańskiej ostatnich dekad. Jednocześnie nowa powieść kryminalna podkreśla nieufność wobec prawa i wymiaru sprawiedliwości. Odrzuca też koncepcję jedynej, obiektywnej prawdy ${ }^{4}$.

Nowa powieść kryminalna w poszczególnych krajach Ameryki Łacińskiej ma swoją specyfikę; dostosowuje się do lokalnych uwarunkowań i tradycji literackiej. Dlatego też tak zwana narkopowieść pojawia się najpierw w krajach najmocniej i najwcześniej dotkniętych problemem narkotykowym, z czasem rozprzestrzeniając się w regionie tak, jak rozprzestrzenia się przestępczość z nim związana. Najpierw pojawia się w Kolumbii, już w latach siedemdziesiątych, a szczególnie intensywnie tuż po upadku wielkich karteli, w ostatniej dekadzie XX wieku i pierwszej XXI. W ostatnich latach narkopowieść rozwija się przede wszystkim w Meksyku, bo też tam jest dziś centrum narkobiznesu i związanej z nim przemocy.

\section{Definicja i cechy narkopowieści}

Większość moich spostrzeżeń na temat narkopowieści jako podgatunku kryminału opiera się jednak na badaniach powieści kolumbijskich, ponieważ stanowi ona już zamknięty korpus. Temat wprawdzie nie zniknął, ale powieści publikowane po 2010 roku nie są już faktycznymi literackimi przedstawieniami apogeum ery narkobiznesu, lecz proponują bardziej psychologiczne lub historyczne podejście do spuścizny po tamtej epoce. Choć można już wyciągnąć wstępne wnioski na temat konwencji narco w innych krajach, mają one jednak prowizoryczny charakter, bo wciąż przybywa materiału do analizy.

Polskim odbiorcom narkopowieść jest mało znana, gdyż znakomita większość kolumbijskiego i meksykańskiego korpusu nie została u nas wydana. Spośród narkopowieści kolumbijskich opublikowano w naszym kraju dwie najbardziej znane na świecie, to jest Matkę Boska platnych morderców (La Virgen de los sicarios, 1994; wyd. pol. 2005) Fernando Vallejo i Rosario Tijeras (1999; wyd. pol. 2007)

${ }^{3}$ Zob. A.S. Jastrzębska, Novela criminal colombiana: muerte como marca comercial, „Fragmentos: Revista de Língua e Literatura Estrangeiras" 22, 2014, nr 1, s. 95-108.

${ }^{4}$ Por. J.F. Noguerol, Neopolicial latinoamericano: el triunfo del asesino, „Ciberletras: Revista de crítica literaria y de cultura” 2006, nr 15, https://bit.ly/3kAxhD0 (dostęp: 15.07.2021). Noguerol proponuje określenie ,neopolicial”, natomiast polska badaczka współczesnej literatury latynoamerykańskiej, Nina Pluta, używa w odniesieniu do tego typu literatury terminu „konwencja pseudokryminalna” lub ,efekt pseudokryminalny”. Zob. eadem, La sombra del crimen. De la influencia del género crominal en la narrativa hispanoamericana del cruce de los milenios, Kraków 2012, s. 40-59.

Literatura i Kultura Popularna XXVII, Wrocław 2021

(C) for this edition by CNS 
Jorge Franco, ponadto Delirio (2004; wyd. pol. 2005) Laury Restrepo, Lamparta w stońcu (Leopardo al sol, 1993; wyd. pol. 2005) tej samej autorki oraz Hatas spadajacych rzeczy (El ruido de las cosas al caer, 2011; wyd. pol. 2013) Juana Gabriela Vásqueza. Narkopowieści meksykańskie choćby tak znanych na świecie autorów jak Elmer Mendoza, Yuri Herrera czy Juan Pablo Villalobos w Polsce pozostają nieznane 5 .

Tak zwana narkopowieść jest nie tyle gatunkiem, ile podgatunkiem lub pochodną powieści kryminalnej, charakteryzującą się pewną konwencją i związaną z nią poetykąa . Narkopowieść definiujemy jako tę odmianę powieści kryminalnej czy - trafniej - czarnej powieści, w której narkobiznes (szeroko rozumiany: nie tylko jako handel, ale także, a może przede wszystkim, jako źródło szybkiego i spektakularnego wzbogacenia się) i jego szeroko pojęte konsekwencje społeczne i kulturowe determinują konfiguracje świata przedstawionego w powieści. $\mathrm{W}$ różny sposób wpisuje się $\mathrm{w}$ literaturę gatunkową i różna jest jej relacja $\mathrm{z}$ tak zwaną literaturą wysoką. W Kolumbii na przykład rodzi się ona jako dziecko literatury faktu i tak zwanej powieści o przemocy, odmiany literatury wysokoartystycznej; jej związki z gatunkiem kryminału są luźniejsze i dyskusyjne, bo w Kolumbii kryminału jako gatunku nigdy nie ceniono, autorzy nie podpisują się więc otwarcie pod tą tradycją ${ }^{7}$. Niemniej, analizując korpus kilkunastu narkopowieści kolumbijskich, możemy zaobserwować pewien zestaw cech charakterystycznych:

- świat przedstawiony oparty na kontrastach i dychotomiach oddających te napięcia, które istnieją w społeczeństwach latynoamerykańskich i do pewnego stopnia przyczyniły się do rozwoju narkobiznesu;

- antyrealistyczne zniekształcenie bohatera i jego otoczenia przez hiperbolizację lub rozmaity stopień mityzacji (demityzacji), w której pobrzmiewają echa prymitywnego, ludowego postrzegania rzeczywistości ${ }^{8}$;

${ }^{5}$ W ostatnim czasie obserwuje się pewne zainteresowanie wśród polskich wydawców najnowszą literaturą kryminalną z Meksyku, co może zmienić tę sytuację. W 2016 ukazała się na przykład powieść Martina Solaresa Nie przysyłajcie kwiatów (No manden flores) w przekładzie Tomasza Pindla. O rzeczywistości przemocy związanej z narkobiznesem w Meksyku częściowo traktuje też powieść Roberto Bolaño 2666 (wyd. pol. 2012).

${ }^{6}$ Konwencję rozumiemy tu jako zespół reguł rządzących konfiguracją świata przedstawionego, dobór składników dzieła, ich hierarchizację, funkcje i relacje z innymi elementami utworu. Mówiąc o poetyce, mamy zaś na myśli przede wszystkim językowy i estetyczny wymiar narkopowieści.

${ }^{7}$ Najbardziej znanym przedstawicielem nurtu novela de la violencia, czyli powieści o przemocy, jest Gabriel García Márquez, autor takich powieści, jak Szarańcza i Zła godzina. Zob. M.H. Rueda, La violencia y sus huellas. Una mirada desde la narrativa colombiana, Madrid 2011. O powieści kryminalnej w Kolumbii pisze zaś Hubert Pöppel w monografii La novela policíaca en Colombia (2001). W niniejszej pracy, wbrew kolumbijskim kontrowersjom, a zgodnie ze stanowiskiem współczesnych cytowanych tu badaczy, traktujemy narkopowieść jako odmianę czarnej powieści.

8 Ten aspekt narkopowieści pozwala niekiedy dostrzec jej pokrewieństwo z realizmem magicznym, zakorzenienie w tej samej wizji świata i mentalności, różniącej się jedynie stopniem nowoczesności entourage’u. 
— intermedialność: dialog z innymi mediami (kino, telewizja) i ogólniej — kulturą masową;

— bezpośrednie uczestnictwo, wyrażane zwykle przez narrację pierwszoosobową;

- echa oralności w narracji;

— różnorodność rejestrów i stylów, która pozwala interpretować narkopowieść jako dynamiczną konfrontację różnych paradygmatów kulturowych ${ }^{9}$.

Zwłaszcza ta ostatnia cecha sprawia, iż narkopowieść jest uznawana za podgatunek estetycznie i etycznie kontrowersyjny, tym bardziej że nawiązuje pewien dialog z tak zwaną narkokulturą (estetyką, obyczajowością i aksjologią środowisk związanych z narkobiznesem). Bywa, iż narkopowieści, pisane przez uznanych w kraju i na świecie pisarzy, utwory o wysokiej jakości artystycznej, sąsiadują na rynku wydawniczym z produktami rzeczonej narkokultury: wspomnieniami skruszonych członków karteli, dawnych miss uwikłanych w brudne interesy, biografiami słynnych narcos (narkotykowych bossów) lub książkami dziennikarzy czy socjologów badających te zjawiska z perspektywy właściwej dla swych profesji ${ }^{10}$. Istnieje też wyraźne pokrewieństwo między narkopowieścią a kulturą masową i jej sztandarowym produktem w Ameryce Łacińskiej: telenowelą. Spośród rozlicznych seriali o ,życiu i twórczości” narkotykowych bossów część inspirowana jest powieściami lub przynajmniej zapożycza ich tytuły, na przykład Rosario Tijeras czy Królowa Potudnia.

\section{Szekspirowskie echa w narkopowieści}

Trudno mówić o bezpośrednich intertekstualnych nawiązaniach do twórczości Szekspira w narkopowieści ${ }^{11}$. To raczej rzeczywistość, z której czerpie ten pod-

9 W przypadku Kolumbii, kraju aspirującego do miana „ojczyzny gramatyków”, jest to przede wszystkim przeniesienie na grunt literackiej fikcji pozaliterackich sporów o rację bytu kultury popularnej, ludowej w stosunku do kultury wysokiej, elitarnej, sporu kulturalnego centrum reprezentowanego przez wykształcone elity i prowincji rozciągającej się poza stolicą. W Meksyku ten geograficzny i regionalny wymiar ścierania się paradygmatów kultury jest jeszcze bardziej widoczny, gdyż pierwotnie kontrowersje kulturowe wiązały się z rywalizacją na linii miasto Meksyk, czyli stolica, a północ kraju, gdzie narodziła się meksykańska narkopowieść.

10 Ten typ literatury o narkobiznesie, o zróżnicowanej wartości poznawczej i artystycznej, pojawił się również w Polsce. Ukazały się na przykład książki Księgowy mafii (2010), wspomnienia Roberta, brata Pablo Escobara i księgowego kartelu, oraz Kochając Pabla, nienawidzac Escobara (2017), wspomnienia kochanki Escobara, Virginii Vallejo. Istnieją również ciekawe prace dziennikarzy, chociażby El Narco (2012) Ioana Grillo, Ameksyka Eda Vulliamy'ego (2012), reportaże z północy Meksyku, ze strefy przygranicznej z USA czy Zero, zero, zero (2014) Roberto Saviano o kokainie i związanym z nią przemyśle.

11 Szekspir nie wydaje się szczególnie popularnym literackim punktem odniesienia w Ameryce Łacińskiej. Być może należy to tłumaczyć mocnym zakorzenieniem całego świata hiszpańskojęzycznego w tradycji cervantesowskiej i hiszpańskiego Złotego Wieku. Obserwacje te nie aspi- 
gatunek czy typ powieści, jest tutaj szekspirowska. Świat narkobiznesu i jego kultura są szekspirowskie par excellence: praktycznie nieobecne jest tam nowoczesne prawo, są za to silne emocje, namiętności, wszechobecna przemoc i zależności niemal feudalne. Kartel to często królestwo: capo jest królem, a poszczególne osoby na różne sposoby wpisujące się w jego działalność to trybiki w maszynie, która działa, by umacniać „królewską” władzę. Narkobiznes i związana z nim przemoc przybierają też niejednokrotnie szalenie teatralne formy, potwierdzając, że „cały świat to scena". W związku z tym mówię raczej o echach szekspirowskich lub duchu Szekspira niż tropach, motywach czy nawiązaniach jako takich.

Jedną z płaszczyzn, na których objawia się ta „szekspirowskość” tematyki, to kwestia władzy, jak w Makbecie czy Juliuszu Cezarze. Narkokultura to w dużej mierze kult jednostki, mamy tu do czynienia z całym swoistym panteonem antybohaterów romantycznych, nazywanych często i charakteryzowanych przez swoją „funkcję": El Rey (Król), El Capo (Szef) czy Comandante Paraíso (Komendant Raj). W tych postaciach literackich rozpoznajemy cechy prawdziwych słynnych narcos: Pablo Escobara czy Chapo Guzmána, by wspomnieć tylko o tych najsławniejszych ${ }^{12}$. W narkopowieści meksykańskiej te postaci ze szczytu narkobiznesu często są w centrum, podczas gdy narkopowieść kolumbijska pokazuje raczej dół hierarchii. I o ile narkopowieść w Kolumbii skupia się na procesie stawania się przestępcą, o tyle meksykańska pokazuje bohaterów w szczytowej formie lub przedstawia proces odwrotny - upadek.

Powieść Fiesta en la madriguera Juana Pabla Villalobosa pokazuje od wewnątrz świat, w którym żyje potężny narkotykowy baron. Narratorem jest jego siedmioletni syn. Logika i narracja dziecięca decydują o charakterze tej powieści: naiwne spojrzenie dziecka pozwala dostrzec, że świat władzy to również świat wiecznego strachu przed jej utratą. Chłopiec opowiada o swoim życiu w pałacu, o pieniądzach w rozmaitej walucie, których ojciec ma mnóstwo, o kosztownościach i o tym, jak bardzo trzeba to chronić, jakie zagrożenia czyhają w świecie na narkotykowego bossa i jego syna. Jednocześnie pozycja narkotykowego barona porównywana jest do pozycji króla, poprzez czytelne aluzje do koron i nakryć głowy, które wskazują, kto jest kim, a także poprzez nawiązania do znanej meksykańskiej piosenki El Rey. W ostatniej scenie dziecięcy narrator przygląda

rują jednak do rangi hipotezy naukowej, są luźnym spostrzeżeniem na podstawie jednostkowego doświadczenia piszącej te słowa. W powieści El ruido de las cosas al caer Juana Gabriela Vásqueza Priscilla Gac-Artigas (,El ruido de las cosas al caer” o la reconstrucción de una era, „Revista de la Academia Norteamericana de la Lengua Española" 4, 2015, nr 7, s. 175-176) dostrzega echa Hamleta, ale to szekspirowskie odniesienie nie odgrywa istotnej roli ani w interpretacji tekstu, ani w jej warstwie estetycznej. Wskazuje raczej na fakt, iż zarówno Szekspir, jak i Vásquez, w dwóch odrębnych epokach, operują tymi samymi archetypami i podobnie postrzegają ludzką naturę.

12 Warto tu wspomnieć o dalekim pokrewieństwie takich narkopowieści z folklorystyczną twórczością poświęconą legendarnym przestępcom i bandytom, jak meksykańskie ludowe corridos, które w czasach wojen narkotykowych stają się narcocorridos. 
się uciętym głowom dwóch hipopotamów z Liberii i z nudów planuje przyjęcie, na którym ukoronuje je koronami ze złota i diamentów ${ }^{13}$.

Również w powieści Trabajos del reino, której autorem jest Meksykanin Yuri Herrera, będącej historią pewnego Artysty, który trafia na „dwór” szefa kartelu, by układać corridos, czyli piosenki sławiące jego „życie i twórczość”, świat władzy to specyficzny mariaż kapitalizmu, którego symbolem są banknoty, globalizacji, symbolizowanej przez waluty i produkty pochodzące z różnych krajów, oraz kultury feudalnej. Boss mieszka w iście królewskim pałacu i jawi się jako nadczłowiek, ktoś „,innej krwi”, kogo wyjątkowość staje się widoczna już w sposobie bycia, wypełniania sobą przestrzeni, respektu, jaki wzbudza samym pojawieniem się. Jest królem, który chroni i ma moc obdarowywania poddanych dobrami, zależnie od ich zasług ${ }^{14}$.

Władza może być celem samym w sobie, ale może też być drogą do celu. W kolumbijskiej powieści Comandante Paraiso, autorstwa Gustavo Álvareza Gardeazábala, bohater, który z biednego wiejskiego półsieroty stał się potężnym i bogatym przywódcą kartelu, zostaje dobroczyńcą rodzinnego miasteczka, wspiera jego rozwój, a jednocześnie snuje plany ,poprawienia świata”. Narkobiznes ma tu być swego rodzaju zemstą na systemie społeczno-politycznym Kolumbii. Narcos jawią się jako apostołowie społecznej sprawiedliwości, ci, którzy wyrównują rachunki w imieniu biednych i wykluczonych, narzucając swój porządek i tworząc nowe elity, zastępujące dotychczasowe. Program tej ,dobrej zmiany” przewiduje też uzależnienie całych Stanów Zjednoczonych od kokainy w akcie zemsty za długoletnią kolonialną politykę wobec krajów latynoamerykańskich ${ }^{15}$.

Trzeci aspekt władzy pojawiający się w narkopowieści dotyczy skutków rządzenia. Na dłuższą metę władza i pieniądze demoralizują i niszczą. Powieść Hijos de la nieve José Libarda Porrasa to studium losów jednej rodziny, w której pewien młody chłopak decyduje się na „karierę” w kartelu. Rodzina szybko się bogaci, przeprowadza do lepszej dzielnicy, prowadzi coraz zamożniejsze życie, ale równocześnie dokonuje się destrukcja więzi między rodzicami a dziećmi, między rodzeństwem i przyjaciółmi ${ }^{16}$. Tak samo w innej kolumbijskiej powieści - Cartas cruzadas, której autorem jest Dario Jaramillo. Tutaj pewien profesor literatury, pracownik uniwersytetu, specjalista od modernizmu, postanawia poprawić swoją sytuację materialną, wchodząc w narkobiznes. Szybko się bogaci i równie prędko przychodzi mu za to zapłacić: staje się ofiarą, na którą polują konkurenci, jest zmuszony się ukrywać, traci wszystko, co miał, i wszystko, czym by $1^{17}$. Te dwa utwory najbardziej jawnie „moralizatorsko” traktują ten temat.

\footnotetext{
13 P.J. Villalobos, Fiesta en la madriguera, Barcelona 2010.

14 Y. Herrera, Trabajos del reino, Cáceres 2010.

15 G.Á. Gardeazábal, Comandante Paraíso, Bogotá 2002.

16 J.L. Porras, Hijos de la nieve, Bogotá 2000.

17 A.D. Jaramillo, Cartas cruzadas, Bogotá 1995.
} 
W większości jednak, jak w Makbecie, ceną władzy jest zbrodnia — i tutaj dotykamy drugiego istotnego aspektu tej „,szekspirowskiej” rzeczywistości narkobiznesu, którą ukazuje narkopowieść. Utrzymanie władzy odbywa się poprzez przemoc i zbrodnię. W powieści Fiesta en la madriguera siedmioletni narrator ujmuje to wprost: „To jak zawody. Koronę bierze ten, kto zgromadzi najwięcej trupów”18.

Przemoc i „produkcja śmierci” związana z narkobiznesem jest dziś swego rodzaju przemysłem, porównywanym przez badaczy do nazistowskiej machiny śmierci, a jednocześnie zbrodnie te są szalenie teatralne, bo każda jest komunikatem, ma stanowić czytelne przesłanie dla innych. To nawet swoisty język: sposób zadania śmierci i umiejscowienie zwłok mają konkretne znaczenie, są informacją.

Paco Ignacio Taibo II, jeden z ważniejszych autorów meksykańskich kryminałów, podkreśla, że w Ameryce Łacińskiej rzadko osoba, która trzyma broń, jest tą samą, która pragnie śmierci ofiary ${ }^{19}$. Zbrodnia jest więc nie tyle aktem, ile procesem. Narkopowieść skupia się tymczasem na dwóch jego końcach: na szefach, którzy zlecają zabójstwa, a jeśli sami zabijają, to często spontanicznie i po to, by udowodnić swoją siłę, dominację i wszechmoc, oraz na płatnych mordercach, nazywanych w Kolumbii sicarios. To często bardzo młodzi ludzie, nawet dzieci (dziesięcio-, dwunasto- czy piętnastoletnie) pochodzące z najuboższych warstw społeczeństwa, zarabiające na życie jako swego rodzaju narzędzie do zabijania.

Powieść poświęcona temu zjawisku doczekała się nawet osobnej, choć kontrowersyjnej, etykiety: novela sicaresca. Jako przykład mogą tu posłużyć dwie najbardziej znane na świecie, w tym w Polsce, narkopowieści: Matka Boska płatnych morderców Fernanda Vallejo i Rosario Tijeras Jorge Franco oraz inspirowana prawdziwą postacią płatnego mordercy, który „odchodzi z zawodu”, Sangre ajena pisarza i dziennikarza Arturo Alape. Każdy z tych utworów ukazuje mechanizm zabijania na zlecenie: przede wszystkim całkowity brak relacji między zabójcą a ofiarą. Uzbrojony w pistolet sicario jest narzędziem, przedłużeniem ręki swego mocodawcy, ale nie wie nic ani o ofierze, ani o motywach zbrodni. To pozwala mu nie czuć się odpowiedzialnym za przelanie cudzej krwi.

W każdej z tych powieści wraca motyw specyficznej religijności młodocianych płatnych zabójców, którzy modlą się o skuteczność w działaniu, o powodzenie w zdobywaniu zleceń, święcą broń i naboje, a spowiadają się z uprawiania seksu z narzeczoną, otwarcie deklarując, że to poważniejszy grzech niż strzelanie do ludzi, bo zbrodnia obciąża sumienie tego, kto ją zleca ${ }^{20}$.

Ostatni przykład zbrodni jako elementu szekspirowskiej rzeczywistości latynoamerykańskiej wiąże się z tamtejszą swoistą kulturą przemocy. W powieści Laury Restrepo Lampart $w$ stońcu dwie spokrewnione rodziny trwają w zadaw-

18 J.P. Villalobos, op. cit., s. 29; jeśli nie podano inaczej, przeł. A.S.J.

19 J.F. Noguerol, op. cit.

${ }^{20}$ F. Vallejo, Matka Boska płatnych morderców, przeł. M. Szafrańska-Brandt, Warszawa 2007; J. Franco, Rosario Tijeras, przeł. T. Pindel, Wołowiec 2005; A. Alape, Sangre ajena, Barcelona 2000.

Literatura i Kultura Popularna XXVII, Wrocław 2021

(C) for this edition by CNS 
nionym konflikcie (jak Capuleti i Montecchi w sztuce Romeo i Julia), w błędnym kole zbrodni i zemsty. Kiedy ktoś z jednej rodziny zabija członka drugiej, na oba rody spada swoista klątwa. Konflikt dziedziczą kolejne pokolenia. W rocznicę pierwszego zabójstwa rodzina zabitego mści się na którymś z mężczyzn z rodu zabójcy. Tamci po jakimś czasie dokonują zemsty i w ten sposób trwają w nieprzerwanym cyklu zbrodni, bo „za krew płaci się tylko krwią”, a w tym świecie jedyna sprawiedliwość to ta, której dokonuje się własną ręką, bo nie ma sędziego, adwokata ani sądu. Zbrodnia staje się rytuałem, mechanicznym wypełnianiem odwiecznego prawa ${ }^{21}$. Tutaj wprost mówi się o tym, co charakterystyczne dla narkopowieści i szalenie szekspirowskie - opiera się ona na koncepcji sprawiedliwości rozumianej tak, jak pewnie pojmowano ją w czasach Szekspira. Pomiędzy ofiarą a zabójcą nie stoi zinstytucjonalizowany porządek prawny.

Podsumowując to pobieżne omówienie, chcę podkreślić, że narkopowieść w Ameryce Łacińskiej jest w zasadzie produktem swoiście szekspirowskiej rzeczywistości i kultury, choć sam William Szekspir jako autor nie bywa w niej przywoływany. Utwory, o których mowa, sytuują nas jednak w uniwersum z jednej strony ultranowoczesnym, z drugiej - niezmiernie archaicznym, przedstawiają paradygmat kultury obcej europejskiej tradycji powieści kryminalnej. Pozostaje więc zadać pytanie: czy kryminał, w którym nie chodzi o to, kto zabił, w którym świat zbrodni zdaje się rozkwitać, a świat prawa nie istnieje, jest wciąż kryminałem? Czy w przypadku latynoamerykańskiego wariantu powieści o zbrodni mamy do czynienia ze złamaniem, przemodelowaniem czy rozszerzeniem reguł gatunku i praw konwencji kryminalnej? Tłem dla tych literackich transgresji jest „szekspirowska” rzeczywistość, która okazuje się katalizatorem przemian w obrębie literackiej konwencji.

\section{Bibliografia}

\section{Teksty}

Alape A. Sangre ajena, Seix Barral, Barcelona 2000.

Bolaño R., 2666, przeł. K. Okrasko, J.W. Rajter, Muza, Warszawa 2012.

Escobar R., Fisher D., Księgowy mafii, przeł. G. Woźniak, Świat Książki, Warszawa 2010.

Franco J., Rosario Tijeras, przeł. T. Pindel, Wydawnictwo Czarne, Wołowiec 2005.

Gardeazábal G.Á., Comandante Paraíso, Grijalbo, Bogotá 2002.

Grillo I., El narco, przeł. A. Górka, Wydawnictwo Remi, Warszawa 2012.

Herrera Y., Trabajos del reino, Periférica, Cáceres 2010.

Jaramillo A.D., Cartas cruzadas, Alfaguara, Bogotá 1995.

Porras J.L., Hijos de la nieve, Planeta, Bogotá 2000.

Restrepo L., Delirio, przeł. E. Morycińska-Dzius, Amber, Warszawa 2005.

Restrepo L., Lampart w słońcu, przeł. W. Ignas-Madej, Amber, Warszawa 2005.

Saviano R., Zero, zero, zero, przeł. J. Kluza, Wydawnictwo Sonia Draga, Katowice 2014.

${ }^{21}$ L. Restrepo, Lampart w słońcu, przeł. W. Ignas-Madej, Warszawa 2005. 
Solares M., Nie przysyłajcie kwiatów, przeł. T. Pindel, Wydawnictwo W.A.B., Warszawa 2016.

Vallejo F., Matka Boska płatnych morderców, przeł. M. Szafrańska-Brandt, Muza, Warszawa 2007.

Vallejo V., Kochając Pabla, nienawidząc Escobara, przeł. K. Okrasko, A. Ostrowska, Agora SA, Warszawa 2017.

Vásquez J.G., Hałas spadajacych rzeczy, przeł. T. Pindel, Muza, Warszawa 2013.

Villalobos J.P., Fiesta en la madriguera, Anagrama, Barcelona 2010.

Vulliamy E., Ameksyka. Wojna wzdluż granicy, przeł. J. Ochab, Wydawnictwo Czarne, Wołowiec 2012.

\title{
Opracowania
}

Gac-Artigas P., ,El ruido de las cosas al caer” o la reconstrucción de una era, „Revista de la Academia Norteamericana de la Lengua Española" 4, 2015, nr 7, s. 165-180.

Jastrzębska A.S., Novela criminal colombiana: muerte como marca commercial, „Fragmentos: Revista de Língua e Literatura Estrangeiras” 22, 2014, nr 1, s. 95-108.

Pluta N., La sombra del crimen. De la influencia del género crominal en la narrativa hispanoamericana del cruce de los milenios, Wydawnictwo Naukowe Uniwersytetu Pedagogicznego w Krakowie, Kraków 2012.

Pöppel H., La novela policíaca en Colombia, Editorial Universidad de Antioquia, Medellín 2001.

Rueda M.H., La violencia y sus huellas. Una mirada desde la narrativa colombiana, Iberoamericana/Vervuert, Madrit 2011.

Valencia S., Capitalismo gore, Melusina, Barcelona 2010.

Zawierzeniec M., Las voces sordas. El capital creativo del México contemporáneo en su contexto socio-cultural (1985-2015), Instytut Studiów Iberyjskich i Iberoamerykańskich, Warszawa 2016.

\section{Źródla internetowe}

Noguerol J.F., Neopolicial latinoamericano: el triunfo del asesino. „Ciberletras: Revista de crítica literaria y de cultura" 2006, nr 15, https://bit.ly/3kAxhD0 (dostęp: 15.07.2021).

Rincón O., Todos llevamos un narco adentro-un ensayo sobre la narco/cultura/telenovela como modo de entrada a la modernidad, „MATRIZes” 7, 2013, nr 2, s. 1-33, https://bit.ly/3zaRNhq (dostęp: 15.07.2021).

\section{The Latin American Narconovel: Reality with Shakespeare in the Background}

\author{
Summary
}

Latin American literature is not rich in references to the works of Shakespeare, but rather focuses on its own tradition. The premise on which this article is based, however, is that the reality of the region displays Shakespearean characteristics.

The aim of this article is to present a subgenre, or a literary convention, known as a narconovel. The configuration of the represented world in this noir novel variant is determined by the drug trade with its far-reaching social and cultural implications. 
The narconovel is an important part of the most recent literature in Colombia, Mexico, and other countries of the region. This article addresses associations and disassociations between the narconovel and the crime fiction convention, centering on Shakespearean motifs, related in this case to the concepts of power, crime, guilt, and punishment. 
Literatura i Kultura Popularna XXVII, Wrocław 2021

(C) for this edition by CNS 